\title{
MITYCZNO-SYMBOLICZNY KONTEKST NOSTALGII W WYGNANIU ANDRIEJA ZWIAGINCEWA W ŚWIETLE ANTROPOLOGICZNEJ NIEPEWNOŚCI PODMIOTU
}

\author{
MYTHICAL AND SYMBOLIC CONTEXT OF NOSTALGIA \\ IN THE BANISHMENT BY ANDREY ZVYAGINTSEV IN THE LIGHT \\ OF ANTHROPOLOGICAL UNCERTAINTY OF THE SUBJECT
}

\author{
ANNA KATARZYNA PRZYBYSZ
}

\begin{abstract}
Aвstract. The aim of this article is to reveal the mythical, symbolic and religious context in the film The Banishment. We also try to show how the nostalgia felt by the heroine can be associated with the state of anthropological uncertainty.
\end{abstract}

Keywords: Andrey Zvyagintsev, mythical context, nostalgia, anthropological uncertainty, cyclicality

Anna Katarzyna Przybysz, Uniwersytet im. Adama Mickiewicza w Poznaniu, Poznań Polska, anna.przybysz@amu.edu.pl

ORCID ID: 0000-0002-2955-5857

Z nazwiskiem Andrieja Zwiagincewa szersza publiczność zapoznała się w 2003 roku dzięki pierwszemu pełnometrażowemu dziełu rosyjskiego reżysera - Powrotowi - filmowi, który nie tylko zdobył uznanie krytyków, ale i został laureatem Złotego Lwa na festiwalu filmowym w Wenecji. Kolejne dzieło, pochodzącego z Nowosybirska twórcy, ukazało się cztery lata później i zostało zatytułowane Wygnanie. Premiera filmu odbyła się podczas 60. Międzynarodowego Festiwalu Filmowego w Cannes, a sam obraz brał udział w głównym konkursie (ostatecznie zwyciężyły 4 miesiace, 3 tygodnie i 2 dni Cristiana Mungiu). Odtwórca głównej męskiej roli w filmie (który grał także w debiucie reżyserskim Zwiagincewa) - Konstantin Ławronienko - został nagrodzony Złotą Palmą dla najlepszego aktora. Z kolei operator - Michaił Kriczman - był nominowany do Europejskiej Nagrody Filmowej (The European Film Awards). Także kolejne pełnometrażowe dzieła rosyjskiego twórcy każdorazowo budziły zainteresowanie krytyki i stawały w szranki o prestiżowe nagrody. Elena (2011) swą światową premierę miała podczas 64. Międzynarodowego Festiwalu Filmowego w Cannes, gdzie otrzymała Nagrodę Jury. Lewiatan (2014) z kolei został zaprezentowany podczas 67. Międzynarodowego Festiwalu Filmowego w Cannes i brał udział w Konkursie Głównym oraz 
otrzymał nagrodę za najlepszy scenariusz (autorstwa Zwiagincewa i Olega Niegina). Obraz ten walczył także o Oscara dla najlepszego filmu nieanglojęzycznego podczas 87. ceremonii wręczenia Oscarów (ostatecznie wygrała Ida $\mathrm{w}$ reżyserii Pawła Pawlikowskiego). O tym jak zacięta była rywalizacja między polskim a rosyjskim obrazem niech świadczy fakt, że w 72 . konkursie Złotych Globów tym razem to Lewiatan otrzymał nagrodę za najlepszy film nieanglojęzyczny, wygrywając z Idą. Ostatni jak dotąd obraz reżysera - Niemiłość - który swą rosyjską premierę miał w czerwcu 2017 roku, także oficjalnie zadebiutował w Cannes, podczas 70. Międzynarodowego Festiwalu Filmowego. Film brał udział w Konkursie Głównym oraz otrzymał Nagrodę Jury. Ten nieco encyklopedyczny wstęp, w którym wymieniam najważniejsze dla świata filmu nagrody i nominacje, które wywalczyły sobie dzieła Zwiagincewa (pomijam tym samym szereg rosyjskich nagród), w moim rozumieniu powinien dobitnie świadczyć o tym, iż każde z filmowych dzieł reżysera Powrotu zasługuje na baczną uwagę, a przede wszystkim pogłębioną interpretację. W każdym z przywołanych powyżej obrazów już nawet najmniejsze jednostki kompozycyjne - pojedyncze kadry, winny zostać poddane wnikliwej analizie, zaś wszystkie dzieła, ze względu na zastosowaną metodę twórczą oraz podejmowaną problematykę bez wątpienia mogą być postrzegane jako metatekst rosyjskiego twórcy.

Akcja drugiego pełnometrażowego dzieła Zwiagincewa rezonuje wokół skomplikowanych relacji współmałżonków (w tych rolach wspomniany już Konstantin Ławronienko, wcielający się w postać Aleksa oraz szwedzka aktorka Maria Bonnevie, która zagrała rolę Wiery). Obraz stanowi fragment opowieści z życia wspomnianej pary oraz jej dwojga dzieci - Kira i Ewy. Zmęczeni dotychczasowym życiem oraz problemami, w poszukiwaniu odpoczynku i z nadzieją, że wraz ze zmianą otoczenia znajdą ukojenie oraz upragniony spokój, postanawiają spędzić czas w rodzinnym domu mężczyzny.

Przeprowadzka do starego, zaniedbanego, opuszczonego budynku, za sprawą optyki, w jakiej zostają ukazane przygotowania miejsca do zamieszkania: odsłanianie okien, wypakowywanie rzeczy, rozpalenie ognia, przywodzi na myśl powrót do arkadii. Na takie skojarzenie naprowadzają także nieco wcześniejsze kadry, w których po raz pierwszy dom pokazany zostaje od wewnątrz: widz obserwuje mocno zaciemnione wnętrze, które wraz ze ściąganiem okiennic powoli wypełnia się światłem, co pozwala dostrzec stojący w oddali masywny kominek, do którego konsekwentnie zbliża się oko kamery. Już na tym etapie odbiorca jest w stanie asocjacyjnie połączyć dany obraz z motywem ogniska domowego i symbolicznym „wydobywaniem” $\mathrm{z}$ mroku, tym bardziej, że w kolejnym fragmencie ujrzy on wesoło trzaskający ogień, przy którym ogrzewają się najmłodsi domownicy. Sam proces „oswajania" nowej przestrzeni, również niejako zapowiada symboliczne wznieca- 
nie żaru ogniska domowego. Warto przy tym zauważyć, że w scenie kąpieli oprócz naturalnej w takich okolicznościach beztroski dzieci oraz nieodczuwania przez nich wstydu, kadry (także za sprawą imienia dziewczynki) mogą budzić asocjacje z biblijnym Edenem sprzed zerwania zakazanego owocu, a więc z prapoczątkiem ludzkości.

Także przestrzeń na zewnątrz sprawia wrażenie stylizowanej na krainę wiecznej szczęśliwości: cicha, spokojna okolica, dom otoczony połaciami łąk i drzewami, sielankowa atmosfera dziecięcych zabaw. W scenie, kiedy Aleks wraca z metalową balią, warto zwrócić uwagę na zastosowanie chwytu geometryzacji przestrzeni, z którego Zwiagincew tak chętnie korzysta w swoich filmach [Bogusz-Tessmar et al. 2017: 69-90]. Kadry przedstawiają jedną $\mathrm{z}$ fasad budynku na tle otaczającej przestrzeni. Dom usytuowany jest u podnóża wzniesienia w niewielkim zagłębieniu terenu. Najprawdopodobniej po to, aby wyrównać poziom całej konstrukcji, został on osadzony na drewnianych balach. Perspektywa, z jakiej budynek zostaje ukazany, powoduje, że dolne krańce prawego i lewego boku zabudowania wyglądają jakby "ginęły" w podłożu, zaś sam dom był „rozpięty” pomiędzy dwoma wzniesieniami. Jego centralna część, pod którą znajduje się wolna przestrzeń, w rezultacie kąta, jaki obrało oko kamery, zdaje się znajdować nieco niżej od skrajnych punktów, a takiej iluzji sprzyja obecność drewnianego tarasu, który optycznie "obniża” tę część budowli. W wyniku sposobu wykadrowania obiektu, widz może odnieść wrażenie, że zarys dolnej linii budynku swym kształtem przypomina łuk. Dana metaforyzacja przestrzeni uruchamia symboliczne sfery odniesień danego obrazu - budzi asocjacje z łodzią (za sprawą „wygiętej” podstawy), a nawet z biblijną Arką Noego, legitymizowane za sprawą nośności znaczeniowej balii niesionej przez Aleksa. Warto także zwrócić uwagę na krzew rosnący w pobliżu domu. Wiotkie witki poruszane przez wiatr mogą w nakreślonym powyżej kontekście przywoływać na myśl gałązki oliwne. Uruchomiony powyżej biblijny kontekst, sprzężony z odnalezieniem spokojnej przystani rezonuje także $\mathrm{z}$ wcześniejszymi ujęciami przedstawiającymi wnętrze szopy, z której Aleks wyniósł metalową balię. Z pozoru wnętrze, w którym znajdują się stare sprzęty, niczym się nie wyróżnia. Jednak w nakreślonym powyżej polu asocjacji odsłonięciu ulega ideowa warstwa obranej kompozycji: $w$ centrum kadru znajduje się przygotowane ze słomy leże, oświetlone przez wpadający przez okno snop światła. Legowisko to może budzić asocjacje $\mathrm{z}$ ewangelicznym żłobem (w kategoriach zrymowanej asocjacji można byłoby także rozpatrywać scenę, która następuje kilka minut później - kiedy Kir głaszcze małego osiołka), a więc symbolicznie zaświadczać o rozpoczęciu nowego etapu w życiu. Bardziej czytelna sublimacja idei bezpiecznej przystani (zespolona z asocjacją z Arką Noego) dostrzegalna jest w scenie, kiedy Kir wraz z Gieorgijem wchodzą do innego budynku, osadzonego na 
metalowej konstrukcji. Oko kamery ustawione zostało w taki sposób, aby od dołu (z poziomu ziemi) obserwować chłopca i mężczyznę, wspinających się po stopniach. Kształt domu wraz z podłożem ponownie swym zarysem przypomina łuk (zresztą szeroki plan, w jakim zostało ukazane przybycie mężczyzn wraz z dziećmi do danego miejsca również powoduje, że wspomniany budynek przypomina łódź). Wzmocnienie biblijnego pola skojarzeniowego następuje także za sprawą przedstawienia otoczenia danej konstrukcji. Sposób kadrowania sprawia, że tło zdominowane zostaje przez błękit nieba i biel obłoków, które intuicyjnie budzą asocjacje z wodną tonią, po której poruszała się wspomniana Arka. Tak więc za sprawą szeregu zastosowanych chwytów artystycznych miejsce, do którego przybyli małżonkowie, może być postrzegane jako reprezentacja azylu, miejsca schronienia przed przeciwnościami losu oraz gwarant cichego, spokojnego życia.

Jednak pobyt $\mathrm{w}$ rodzinnym domu mężczyzny i wydarzenia, do jakich w nim wkrótce dojdzie, sprawią, że widz będzie je postrzegał jako jeden (choć nie jedyny) ze sposobów realizacji tytułowej idei „wygnania”. W węższym, biblijnym znaczeniu jako „Wygnanie z Raju”, reprezentacja „świata bez Boga" - co zdaniem części badaczy stanowi dosyć pretensjonalny przykład epigoństwa, tak względem twórczości artystycznej Andrieja Tarkowskiego, jak i poprzedniego dzieła samego Zwiagincewa - Powrotu [por. Sobolewski, Felis, Kurz, Hollender]. Pomimo sielankowej atmosfery, którą można odczuć $\mathrm{w}$ pierwszych momentach zasiedlania domu, niedługo po przybyciu idylla się kończy: Wiera oznajmia mężowi, że jest w ciąży, natomiast dziecko, którego się spodziewa, nie jest jego. Wyznanie to staje się jednym z momentów zwrotnych w życiu bohaterów - od tej pory widz będzie obserwował napięte relacje między małżonkami, walkę wewnętrzną (wyraźnie wyeksponowaną w przypadku Aleksa, nieco mniej przez jego żonę), związaną z podjęciem trudnej moralnie (i, jak się później okaże, także życiowo) decyzji, a także próbę ratowania tego, co bezpowrotnie zostało utracone.

Bez wątpienia świat wykreowany w Wygnaniu nosi w sobie piętno upadku. Przestrzeń miejska epatuje pustką: wyludnione ulice, budynki, zaniedbane przemysłowe budowle [Kempna-Pieniążek 2013: 89]. Z kolei wieś, choć spokojna i przynajmniej z pozoru nie odpychająca, zdaje się być zaledwie cieniem dawnej arkadii, jej smutnym wspomnieniem, co w warstwie materialnej zostaje bezpośrednio wyeksponowane za sprawą zaniedbanego i częściowo popadającego już w ruinę domu Aleksa, natomiast w metaforycznej przy pomocy pozostałości po krynicznym źródełku, które niegdyś zbierało się w niewielkiej studzience, obecnie zaś wyschło. Stare, zniszczone, zakurzone meble, odrapane ściany, mocno wysłużone sprzęty dobitnie świadczą o tym, iż czasy świetności to miejsce ma już za sobą. Jednak, co ciekawe, akcja filmu zostaje osadzona w przestrzeni, która pozostaje niedookreślona: na próżno 
szukać tu w elementach scenografii lub wypowiedziach bohaterów wskazówek, które naprowadziłyby odbiorcę na miejsce jej rozgrywania. Zarówno miasto, jak i tereny poza nim ukazane zostały w taki w sposób, że brak w nich charakterystycznych punktów, miejsc, dzięki którym odbiorca byłby w stanie zidentyfikować już nie tylko konkretną miejscowość, ale choćby kraj. Z informacji dystrybutora wynika, że film był kręcony we Francji, Belgii, Mołdawii i Rosji, jednak sposób ukazania przestrzeni otaczającej bohaterów został poddany wyraźnej typizacji - zaakcentowano "wyjęcie” tego fragmentu świata z kontinuum czasoprzestrzennego, dzięki czemu wydarzenia, rozgrywające się $\mathrm{w}$ filmie mogą być postrzegane jako rodzaj alegorii, uniwersalistycznego przekazu. Nawet cmentarz czy świątynia, do której udają się bohaterowie (zamknięta!) nie epatują przynależnością do konkretnego wyznania - choć uważny widz dostrzeże np. wielokrotne umiejscawianie krzyża, który stoi nieopodal domu, w kadrach rozgrywających się zarówno na zewnątrz budynku (wtedy oko kamery ustawione jest w taki sposób, że krzyż, choć oddalony, jest zawsze wyraźnie widoczny), jak i wewnątrz (widać go przez okno). Tadeusz Sobolewski zastanawia się, czy w tym filmie aborcja stanowi figurę ukrzyżowania [Sobolewski 2007].

Co więcej, do głównego bohatera pozostali najczęściej zwracają się przy użyciu skróconej wersji imienia Aleksander - Aleks, a ta z kolei zdaje się przesuwać akcent z rosyjskości w stronę uniwersalności ( $w$ języku rosyjskim wspomniane imię można zdrobnić/skrócić na wiele różnych sposobów - Sasza, Szurik, Sania - jednak każdy z nich brzmi bardziej swojsko od przyjętego w filmowej opowieści "kosmopolitycznego" wariantu). Podobnie rzecz ma się z imionami innych męskich bohaterów (choć nie wszystkich, wyjątek w tym kontekście stanowi Gieorgij): Mark, Robert, Maks, Wiktor - każde $\mathrm{z}$ tych imion jest neutralne, tzn. nie budzi w odbiorcy jednoznacznych asocjacji z rosyjskością. Wydaje się więc, że ten szereg zabiegów zorientowany na to, aby „nie umiejscawiać”, nie łączyć opowieści z konkretnym chronotopem umacnia uniwersalną wartość przesłania opowieści. Taki chwyt artystyczny niewątpliwie sprzyja otwartej postawie odbiorcy, jak również jawi się jako klucz, określający sferyczny charakter świadomości współczesnego człowieka [Chałacińska, Przybysz 2016: 175]. Gwoli sprawiedliwości trzeba jednak podkreślić, iż powtórzenie tego zabiegu, znanego już odbiorcy z Powrotu, trąci wtórnością. Paweł Felis wprost oznajmia, że formuła zawieszonej $\mathrm{w}$ bezczasie przypowieści nie sprawdziła się w drugim filmie Zwiagincewa. Zdaniem Felisa ta bezczasowość, która urzekła widza w produkcji, będącej debiutem reżysera, w Wygnaniu przybrała dziwnie skostniałą formę, uległa spłaszczeniu, czy wręcz zastygła w nachalnej symbolice [Felis 2008].

Warto się także przyjrzeć samym kadrom otwierającym filmowe dzieło, które można potraktować jako metaforyczną opowieść o historii cywilizacji. 
Widzimy tu bowiem charakterystyczną, historiozoficzną optykę z jej tradycyjnym podziałem na Starożytność (symbolicznie przedstawianą przez pole), Średniowiecze (las) i Nowe Czasy (miasto). W tej perspektywie droga stanowi reprezentację metahistorii, a rozłożyste, samotnie stojące drzewo - symbol Edenu i przedhistorycznego Raju [Васильев]. Tak więc dzieło rosyjskiego reżysera w swej warstwie ideowo-artystycznej jawi się jako ponadczasowa opowieść, nie osadzona w żadnym konkretnym miejscu ani doprecyzowanym czasie. Za czym więc mogą tęsknić bohaterowie, skoro miejsce, z którego przybyli, opuszczali raczej z poczuciem ulgi i nadzieją na lepsze jutro (przynajmniej takie wrażenie może odnieść widz, a będzie ono spotęgowane w końcowej fazie filmu, kiedy dowiemy się, co przeżywała Wiera w poprzednim mieszkaniu)?

Odpowiedzi na to pytanie należy szukać w tytule filmowego dzieła, który, jak w przypadku każdego z dotychczasowych pięciu filmów Zwiagincewa, stanowi klucz interpretacyjny do symbolicznej warstwy obrazu. Przede wszystkim „wygnanie” budzi asocjacje z biblijnym rajem, który pierwsi ludzie musieli opuścić po akcie nieposłuszeństwa wobec Boga oraz z tęsknotą do krainy beztroski i szczęśliwości. Motyw wygnania doskonale znany jest także z mitologii. Próba interpretacji tytułu filmowego dzieła w kluczu mityczno-religijnej optyki naprowadza na myśl, że nostalgia bohaterów dzieła rosyjskiego reżysera wynikałaby nie tyle $\mathrm{z}$ tęsknoty za jednym, konkretnym określonym rajem, domem, arkadią, ile za określonym porządkiem, całym uniwersum wartości, usystematyzowanym, uporządkowanym światem. I mowa tu nie tylko o odczuciach bohaterów, lecz także twórców i potencjalnych odbiorców filmowego dzieła.

Jak zauważa Bolesław Michałek, nieomal banalnym frazesem jest stwierdzenie, że to w sztuce krytyczne momenty wielkich zmian społecznych czy przemieszczeń świadomości zbiorowej znalazły swój najbogatszy wyraz [1972: 5]. Zdaniem Wojciecha Burszty religijno-mityczne asocjacje powodują, że widz zaczyna odwoływać się do pewnej określonej formy świadomości: takiej, która posiada społeczną funkcję o charakterze ponadczasowym i przedinformacyjnym [Burszta 1997: 120]. Mit bowiem można postrzegać jako specyficzną formę czy strukturę świadomości (dziś zwykle utajoną), która objawia swą moc w obliczu konieczności udzielenia odpowiedzi na ostateczne pytania, jest on bowiem powrotem do tego, co niezmienne [Burszta 1997: 120-122]. Można go także określić jako rodzaj zbiorowej pamięci, albowiem w świadomości mitycznej przeszłość uzyskuje wartość absolutną i ma w pełni jednorodny charakter. Podkreślić przy tym wypada, że klasyczne fabulacje religijne Burszta klasyfikuje jako mity. Chodzi tu oczywiście o aspekt wyprzedzania rzeczywistości i czasu empirycznego, przy jednoczesnym nadawaniu im sensu i stwarzaniu ponadczasowego wzorca, któremu należy dorównać 
(albo przynajmniej go przywołać) po to, aby wskazać ostateczną instancję odwoławczą na rzecz sensowności absolutnej świata albo jego fragmentu [1997: 121]. Także nostalgia jest pewną formą pamięci, która najczęściej może przybierać dwie formy: tęsknoty za określonym miejscem (ojczyzną) lub przeszłością (nierzadko idealizowaną), wspomnieniami [Burszta 1997: 123].

Zastosowanie $\mathrm{w}$ filmowym dziele wspomnianych wcześniej środków wyrazu sprawia, że widz obserwuje osamotnienie bohatera, podejmowane przez niego syzyfowe próby powrotu do przeszłości (nie w sensie temporalnym, lecz emocjonalnym), próby przywrócenia poprzedniego porządku. Staraniom tym towarzyszy melancholijne poczucie braku (jako antywartości), niezrozumienia. Zdaje się, że mowa tu o niedostatku poczucia wspólnotowości, rozumianej zarówno jako bliskość między małżonkami, jak i w szerszym kontekście umiejętność nawiązywania trwałych relacji interpersonalnych (wielokrotnie padają mniej lub bardziej zawoalowane sugestie, dotyczące skomplikowanych relacji ojca i synów - wątek ten znany jest widzom filmów Zwiagincewa także z pozostałych jego dzieł, zarówno wcześniejszego Powro$t u$, jak i późniejszych obrazów).

Obecności nostalgii w filmowym dziele nie należy utożsamiać z jednoznacznie negatywną oceną współczesności (nie chodziłoby tu bowiem o krytykę teraźniejszości, lecz pokrzepiającą moc przeszłości, z którą wiąże się nostalgia [Burszta 1997: 125]), choć bez wątpienia poczucie osamotnienia, motyw domniemanej zdrady, a następnie trudna i okupiona moralnym ciężarem decyzja o dokonaniu aborcji konstruują defetystyczny punkt widzenia odbiorcy. To nie sielankowa przeszłość staje się punktem odniesienia, wymarzonym rajem, który bezpowrotnie utracili bohaterowie, lecz możliwość (ale i chęć) rozmowy, potrzeby przebywania $\mathrm{w}$ towarzystwie współmałżonka, mentalna bliskość, których brak eskaluje poczucie obcości. Wiera wypowiada znamienną frazę: „Му чужие. Ты чужой и всегда был таким. И будешь”. Obecność niewyburzalnej granicy eksponowana jest również za sprawą wyraźnie akcentowanej proksemiki. Podczas próby rozmowy, w trakcie której z ust bohaterki pada bolesna deklaracja wzajemnej obcości/obojętności, małżeństwo zasiada przy dwóch przeciwległych bokach stołu, wzmacniając tym samym wydźwięk danej sceny. Co ciekawe, dzięki zastosowaniu chwytu retrospekcji widz poznaje odpowiedź przynajmniej na część frapujących go pytań: dowiaduje się między innymi o tym, że to Aleks był biologicznym ojcem dziecka. Zatem fraza wypowiedziana przez Wierę (doskonale znającą prawdę), w której zanegowała biologiczne ojcostwo Aleksa, dotyczy aspektów zgoła odmiennych. Wydaje się, że kobieta pomija (drugorzędne w takiej optyce) kwestie ontyczne, sytuując problem w szerszej, ontologicznej perspektywie.

Deklarację bohaterki można traktować jako otwarte pytanie o miejsce człowieka we wszechświecie, o wartość relacji międzyludzkich, a także sta- 
tus kondycji ludzkiej. Wiera mówi: „Он любит нас для себя. Как вещи. [...] Почему я так одинока? Почему он не говорит со мной как раньше? [...] Я должна что-то сделать. Если так будет продолжаться, все умрет. А я не хочу рожать умирающих". Słowa bohaterki świadczą o braku odwzajemnionej, a przede wszystkim prawdziwej miłości w małżeństwie, o zastąpieniu jej reifikującym stosunkiem do bliskich. Żona Aleksa pragnie czegoś więcej: zrozumienia, zaangażowania, empatii, wolności (nierozumianej jako przyzwolenie na zdrady, lecz bipolarna opozycja do manipulatywno-użytkowej reifikacji uprawianej przez Aleksa, wtłaczającej małżonków w pozbawione osobistego zaangażowania relacje). W jej słowach wyraźnie wyczuwalna jest tęsknota za innym porządkiem, a może innym sposobem doświadczania świata: nie skrajnie materialistycznym, nierozerwalnie związanym z potrzebą posiadania (i przez to egoistycznym), lecz za upodmiotowionymi relacjami, zorientowanymi na drugiego człowieka. Bohaterka spogląda na tę wymarzoną krainę szczęśliwości z nostalgią i melancholią, towarzyszy jej przy tym poczucie bezsensowności życia, które wiedzie. Pragnienie Wiery można postrzegać jako próbę zachęty odbiorcy do namysłu, oderwania się od codzienności i chęć wyjścia poza szablonowy, a nierzadko bezrefleksyjny sposób funkcjonowania w otaczającym świecie, do wytrącenia ze stanu duchowego otępienia.

Zwiagincew nie przedstawia jednak całkowicie defetystycznej wizji współczesnej rzeczywistości, pozwalając żywić widzowi nadzieję. Choć bohaterka umiera, to za sprawą sposobu konstruowania narracji i zakodowywania w niej symbolicznej warstwy, aktu tego nie sposób postrzegać jednoznacznie pesymistycznie. Reżyser stosuje tu dosyć czytelny chwyt: w momencie dokonywania aborcji w tym samym czasie dzieci kobiety, na której wykonywany jest zabieg, układają puzzle przedstawiające Zwiastowanie Leonarda da Vinci. Zresztą w samym sposobie przedstawiania Wiery (symbolika koloru jej strojów, cicha pokora, ikonizacja oblicza, w scenach, kiedy kobieta wygląda przez okno oraz przegląda się w lustrze) dostrzegalna jest jej stylizacja na Maryję (choć gwoli sprawiedliwości podkreślić należy ambiwalentny charakter danej postaci: determinację, bezkompromisowość, a także maksymalizm działań, uwydatniające jej demoniczny potencjał). Sama śmierć bohaterki, która nastąpiła $\mathrm{w}$ trakcie snu również budzi asocjacje z Zaśnięciem Bogurodzicy, co podważałoby definitywny charakter odejścia Wiery, otwierając równocześnie możliwość jego metaforycznego postrzegania. Zresztą śmierć bohaterki (jak się później okaże samobójczą) można interpretować $\mathrm{w}$ kategorii ofiary, a ta z kolei wiąże się z dialektyką narodzin i śmierci, a więc umierania i odradzania, początku i końca, sprzężonymi z ideą cykliczności. Wkodowany w symboliczną warstwę dzieła mitologiczny kod [Лотман 2001: 70-673] również umacnia daną narrację. Jako wyraz 
nadziei, a zarazem możliwości zakwestionowania nieodwołalności zaistniałych wydarzeń (mowa o ich symbolicznym wydźwięku) mogą posłużyć wymowne kadry, domykające konkretne fragmenty filmowej opowieści. Wątek rodzinnego domu Aleksa kończą ujęcia, w których krynica znów tryska wodą, z kolei całość dzieła zamyka scena, w której ziemia nie pozostaje jałową, lecz wydaje plon: oczom widza ukazują się kobiety pracujące w polu przy żniwach, co stanowi dosyć czytelną aluzją zarówno do obfitej symboliki ziarna, jak i jego cyklicznego charakteru funkcjonowania, a także do biblijnych konotacji danego motywu. Zwiagincew dostrzega więc szansę: to, za czym tęsknimy, nie musiało zostać bezpowrotnie utracone. Warunkiem odrodzenia nie jest przebywanie z innym człowiekiem, lecz współ-bycie. Stan antropologicznej niepewności, w jakim tkwi podmiot (postrzegany bezpośrednio - w odniesieniu do głównej bohaterki, w szerszym kontekście zaś jako wyraz kondycji ludzkiej jako takiej) może być więc "przełamany” za sprawą nawiązania bliższych relacji z Innym. Cennym w tym kontekście wydaje się spostrzeżenie poczynione przez Michaiła Bachtina, iż człowiek "staje się" w relacjach z innym człowiekiem (co eksponuje fundamentalną rolę dialogu i spotkania z Innym w procesie kształtowania osobowości jednostki (становление личности)). Zdaniem Jeana Baudrillarda, postępująca technicyzacja, mediatyzacja, a przede wszystkim wirtualizacja związana z projektowaniem hiper-rzeczywistości świata stereo i wideo powodują, że podmiotowi brakuje pewnego punktu oparcia [Baudrillard 1994: 254]. Używając określenia francuskiego filozofa $\mathrm{w}$ danym kontekście mam na myśli uprzedmiotowione relacje, brak dialogu z drugim człowiekiem, będące rezultatem funkcjonowania w rzeczywistości, którą sami sobie projektujemy. Doskonały kontekst dla poczynionego wniosku dają pozostałe filmy Zwiagincewa, które funkcjonują we wzajemnej sieci powiązań, tworząc metatekst. W ostatnim jak dotąd dziele reżysera - Niemiłości, widzimy Żenię matkę chłopca, która nieustannie funkcjonuje w wirtualnej rzeczywistości z nosem wetkniętym w ekran smartfona: podczas rozmowy z mężem, śniadania dziecka, w salonie piękności, w trakcie kolacji z ukochanym. Kobieta jest zajęta przeglądaniem różnych profili w portalach społecznościowych lub robieniem zdjęć. Widz odnosi wrażenie, że przebywanie w wykreowanej realności sprawia jej większą przyjemność niż prawdziwe życie. Zresztą tłem dla opowieści o zobojętnieniu, egocentryzmie i braku miłości jest relacjonowana $\mathrm{w}$ mediach wojna na Ukrainie, której przebieg, bez słowa komentarza, bohaterowie śledzą na ekranach swoich telewizorów. Podobny charakter relacji obserwujemy wszakże w Wygnaniu - małżonkowie utracili umiejętność szczerej rozmowy. Relacje, w jakich funkcjonują, sprowadzają się do machinalnego wypełniania rodzicielskich (ale i małżeńskich oraz towarzyskich) obowiązków. Brak tu zaangażowania, empatii, zrozumienia, 
ale i chęci przełamania impasu. Każde z nich żyje w świecie, wykreowanym według własnych zasad, skrojonym na miarę własnych potrzeb. To właśnie tu należałoby upatrywać źródła konfliktu.

Słowa Wiery, że jej mąż kocha ich dla siebie można więc postrzegać w charakterze apelu o waloryzację stosunków międzyludzkich, rezygnację z reifikacji na rzecz upodmiotowienia. Sama bohaterka mówi: „Мы ведь можем жить не умирая. Ведь есть такая возможность. [...] Это можно только вместе. Друг для друга. Сообща. По одному не получается".

\section{Bibliografia}

Бахтин М. М. 1979. Автор и герой в эстетической деятельности. Проблема автора, źródło elektroniczne: http:/ / mmbakhtin.narod.ru/probl.html (dostęp 31.05.2015).

Васильев Е. Препарат профессора Гибберна, źródło elektroniczne: http:/ /az-film.com/ru/ Publications/39-Preparat-professora-Gibberna.html (dostęp 2.11.2017).

Лотман Ю. М. 2001. Семиосфера. Культура и взрыв. Внутри мыслящих миров. Статьи, заметки, исследования, Санкт-Петербург: Искусство-СПБ.

Baudrillard J. 1994. Świat wideo i podmiot fraktalny, przeł. A. Gwóźdź, [w:] A. Gwóźdź, Po kinie?... Audiowizualność w epoce przekaźników elektronicznych (wybór, wprow. i oprac.), Kraków: Universitas, s. 247-258.

Bogusz-Tessmar P., Kaźmierczak N., Królikiewicz N., Przybysz A., Waligórska-Olejniczak B. 2017. Nowe kino rosyjskie wobec tradycji literackiej i filmowej, Poznań: Instytut Filologii Rosyjskiej i Ukraińskiej UAM.

Burszta W. J. 1997. Nostalgia i mit, [w:] E. Domańska (wstęp, przeł. i oprac.), Historia: o jeden świat za daleko?, Poznań: Instytut Historii UAM, s. 119-130.

Chałacińska H., Przybysz A. K. 2016. Fenomen uprzedniości w kulturowej przestrzeni początku $i$ końca. «Czerwony kogut leci wprost do nieba» Miodraga Bulatovica $i$ «Golgota» Czingiza Ajtmatowa, [w:] J. Tymieniecka-Suchanek, A. Polak, M. Karwacka (red.), Rosja w zbliżeniach. Szkice o literaturze rosyjskiej, Katowice: Wydawnictwo Śląsk, s. 175-198.

Felis P. T. 2008. Samotność Wiery, "Gazeta Wyborcza”, nr 73 (27.03.2008), s. 1, 16, źródło elektroniczne: http:/ / wyborcza.pl/1,75410,5059046.html (dostęp 2.11.2017).

Hollender B. 2008. Reżyser zastąił ból kalkulacja, "Rzeczpospolita”, nr 71 (25.03.2008), s. A21, źródło elektroniczne: http://www.rp.pl/artykul/111296-Rezyser-zastapil-bol-kalkulacja.html (dostęp: 2.11.2017).

Kempna-Pieniążek M. 2013. Formuty duchowości w kinie najnowszym, Katowice: Wydawnictwo Uniwersytetu Śląskiego.

Kurz I. 2008. Wygnanie, „Kino”, nr 3, s. 66, źródło elektroniczne: http:/ / kino.org.pl/index. php?option=com_content\&task=view\&id=112\&Itemid=5 (dostęp 2.11.2017).

Michałek B. 1972. Kino naszych czasów, Warszawa: Wydawnictwa Artystyczne i Filmowe.

Sobolewski T. 2007. Totalitarne echa w Cannes, "Gazeta Wyborcza”, nr 116 (19-20.05.2007), źródło elektroniczne: http:/ / wyborcza.pl/1,75410,4143428.html (dostęp 2.11.2017).

Zwiagincew A. 2007. Wygnanie, RENFILM/Россия, Belgia-Rosja. 